IFN Working Paper No. 880, 2011

\title{
Exploring the Long-Term Evolution of Trade Survival
}

Wolfgang Hess and Maria Persson 


\title{
Exploring the Long-Term Evolution of Trade Survival ${ }^{*}$
}

\author{
Wolfgang Hess ${ }^{\dagger} \quad$ Maria Persson ${ }^{\ddagger}$
}

August 19, 2011

\begin{abstract}
Aiming to explore how the survival of trade flows has evolved over time, we analyze a rich data set of detailed imports to individual EU15 countries from 140 non-EU exporters, covering the period 1962-2006. We find that short duration is a persistent characteristic of trade throughout the extended time period that we study: in general only 40 percent of trade flows survive the first year of service, and this share has not changed much since the 1960s. However, this observed constancy is the result of two underlying trends that work in opposite directions. On the one hand, positive trends in several of the observed explanatory variables - which in turn influence the hazard of trade flows dying in a negative direction - imply that the hazard tends to decrease over calendar time. On the other hand, there is also a positive trend in the hazard due to calendar year-specific unobserved factors. Holding all observed determinants constant, the probability of a trade flow dying in its first year increases from $34 \%$ at the beginning of the period to $90 \%$ at the end.
\end{abstract}

JEL Classification: C41; F10; F14.

Keywords: Duration of Trade; Survival; Entry and Exit, European Union; Discrete-Time Hazard Models

* This paper has previously been circulated as 'Exploring the Evolution of Trade Survival Since 1962'. Financial support from the Jan Wallander and Tom Hedelius Foundation under research grant numbers P2009-0189:1 and W2009-0352:1, and from the Marianne and Marcus Wallenberg Foundation is gratefully acknowledged.

${ }^{\dagger}$ Department of Economics and Centre for Economic Demography, Lund University. E-mail: Wolfgang.Hess@nek.lu.se.

${ }^{\ddagger}$ Corresponding author: Department of Economics, Lund University, and Research Institute of Industrial Economics (IFN). Postal address: P.O. Box 7082, S-22007 Lund, Sweden. E-mail: Maria.Persson@nek.lu.se; Tel.: +46462224670. 


\section{Introduction}

Over the last few years, a literature has emerged which focuses on the duration of trade. The number of years that a single bilateral trade flow survives from the first year of trade until the value of trade is again zero for this particular product is measured, and the length of this spell constitutes the main object of study. Early articles by Besedeš and Prusa $(2006 a, b)$ showed that the median duration of US imports was merely one year in their benchmark 7-digit (US Tariff Schedule) data. Later articles, including Hess and Persson (2011b), Besedeš and Prusa (2010), Besedeš (2008, 2011), Nitsch (2009), Fugazza and Molina (2009) and Brenton et al. (2009) have confirmed similar short durations for other countries' trade. For a detailed overview of these studies, see Hess and Persson (2011b). Hess and Persson (2011a) offers a discussion and analysis of the methodology used in the literature.

Existing studies have analyzed the duration of trade across countries and products, and in particular, some have looked into how the probability of trade flows dying evolves over spell time, i.e. depending on how many years the trade relationship has already been in place. For a discussion, see e.g. Besedeš and Prusa (2006a). However, an equally interesting question to ask is how the duration of trade - or, from another perspective, the probability of trade relationships dying - has evolved over calendar time. Then, it is not the years since the beginning of trade one is primarily focusing on, but rather whether the duration of trade was the same in say the 1960s as in the 1990s. In general the existing papers in the literature have covered so short time periods that a proper analysis of the latter question has not been meaningful. ${ }^{1}$

To the best of our knowledge, the first and only paper to have looked into the issue of how the survival of trade flows evolves over calender time is Hess and Persson (2011b). Using a data set of detailed imports to individual EU15 countries from 140 non-EU exporters covering the period 1962-2006, the authors were able to show that short duration is actually a persistent characteristic of trade throughout the extended time period under study. The proportion of trade spells that survive the first year of service was for instance found to be around 40 percent throughout the whole time period. In other words, trade relationships died very early to the same extent in the 1960s as they do today. This is rather remarkable, considering how much more integrated the world economy has become over the same period. Since the 1960s, there have for instance been several rounds of multilateral trade negotiations, a large number of new preferential trade agreements, closer links between

\footnotetext{
${ }^{1}$ For instance, Besedeš and Prusa (2006a,b) and Besedeš (2008) focus on the time period 1972 - 1988 , Nitsch (2009) covers the time period 1995-2005, Besedeš (2011) uses data for 1995-2008 and Fugazza and Molina (2009) have data for 1995 - 2004. Brenton et al. (2009) cover a slightly longer time period - 1985 - 2005 - but do not use it to draw any conclusions regarding the evolution of trade duration over calender time. Besedeš and Prusa (2010), finally, have data for a fairly long time period, 1975-2003, but do not analyze how the duration of trade changes over this period.
} 
economies due to foreign direct investment, modernized means of transportation, financial liberalization etc. Yet, the survival of new trade relationships has remained pretty much constant throughout this period. This is an intriguing result, and the aim of this paper is to shed some light on why this is the case. Towards that aim, we employ the same data set as Hess and Persson (2011b). Estimating a discrete-time duration model with proper controls for unobserved heterogeneity, we use the model's estimated parameters to illustrate how the hazard of trade flows dying has changed due to the factors which we can identify as having an effect on duration, and how it has changed due to unobserved factors that we capture by calendar year dummies. Besides giving insights into why and how the duration of trade does or does not change, this method in a sense gives us an overview of what we can explain about why trade flows survive or not, and what we cannot explain. ${ }^{2}$

The remainder of the paper is organized as follows. Section 2 presents the data used, and reiterates the main findings from the descriptive statistics in Hess and Persson (2011b). Section 3 briefly discusses the empirical strategy and presents the regression results. In Section 4, the regression results are used to illustrate that the observed constancy of trade duration is the result of two underlying trends that work in opposite directions. Section 5 summarizes the main findings, and concludes.

\section{Data and Descriptive Statistics}

The same data as in Hess and Persson (2011b) are used: data from the UN Comtrade Database on imports to EU15 countries from 1962 to $2006 .{ }^{3}$ These data are at the 4digit level, classified according to the Standard International Trade Classification (SITC), Revision 1. As noted by Hess and Persson (2011b), using this relatively aggregated 4-digit data has two advantages. First, unlike customs product codes, according to which more disaggregated data are usually classified, products in the SITC are not reclassified from year to year, which strongly reduces problems with censoring. Second, data at a relatively high level of aggregation yields more conservative estimates, because if we do find short trade spells using relatively aggregated data, we can be more confident that this mirrors an economically significant phenomenon. Besedeš and Prusa (2010) use the same type of data in their analysis.

The sample of exporters consists of all countries that at some point during the observation period exported to any of the EU15 countries. As in Hess and Persson (2011b), two

\footnotetext{
${ }^{2}$ It should be noted that this paper - and the articles cited above - belong in the literature analyzing the duration of country-product-level trade. There is also a literature which analyzes the duration of firm-level trade, where articles include Görg et al. (2007), Volpe-Martincus and Carballo (2008), Ilmakunnas and Nurmi (2010) and Cadot et al. (2011). Not surprisingly, the firm-level data sets used in that literature covers too short time periods to be useful when analyzing how trade survival evolves over calender time.

${ }^{3}$ For simplicity, we will refer to the "European Union", though, of course, this term will not be formally correct in some instances.
} 
groups of countries have, however, been excluded from the sample. First, we exclude all EU27 countries as exporters, since we focus on studying the duration of the EU's trade with the rest of the world. From a practical aspect, it is a convenient choice to exclude intra-EU trade since that trade is to a large extent driven by a complex integration process which is difficult to properly control for. Second, we also exclude former Soviet republics and South East European transition economies, because trade in these centrally planned economies was arguably driven by political rather than economical factors. Following this, we obtain data on EU imports from 140 exporters, covering a broad range of income levels. The sample of exporting countries is shown in Table A.1 in the Appendix.

The empirical strategy is to study the duration of bilateral trade relationships. As importing countries we consider all individual EU15 countries during the whole observation period from 1962-2006. ${ }^{4}$ For each calendar year, we observe the value of any individual EU country's imports from a given country at the 4-digit product level. For every combination of importing country, exporting country, and traded product (referred to as a trade relationship), we calculate the duration of trade as the number of consecutive years with non-zero imports. These different spells of trade constitute the core units of analysis in our empirical study. The number of spells differs from the number of trade relationships since any of the trading parties may choose to terminate the trade relationship and revive it at a later point in time. Such reoccurring trade relationships are referred to as multiple spells of service.

For a detailed descriptive analysis of the data, we refer to Hess and Persson (2011b). Here we will replicate some of the most interesting findings. Almost 60 percent of all observed spells cease during the first year of service. Approximately 75 percent of all trade flows terminate within the first two years, and more than four in five trade relationships only last a maximum of three years. Less than ten percent of all relationships survive the first ten years. Thus, the vast majority of spells will only last for at most a few years, and only a small fraction can be characterized as long-lasting. These are remarkable results when considering both the high level of product aggregation (encompassing a total of only 625 products) and the usage of data at the country level rather than firm level, which would suggest fewer movements in and out of the market. As shown in Hess and Persson (2011b), the conclusion that EU import flows are very short-lived is robust to changes in the way spells are defined, the measurement of trade flows, and, remarkably, even the level of aggregation. ${ }^{5}$

\footnotetext{
${ }^{4}$ Since many EU15 countries join the EU after 1962, we include a dummy variable in our regressions, that indicates for every year of a spell whether the respective importing country has already joined the EU or not. It should be noted that, since Belgium and Luxembourg are treated as one trading block in the statistics, we have data for 14 importers in practice.

${ }^{5}$ To be more precise, Hess and Persson (2011b) find that only considering the first spells which occurred for a given trade relationship in the period or only considering spells where there were no reoccurring trade for that trade relationship does not change the conclusions. Further, ignoring one-, two- or even three-year gaps with no trade does not change the results much, and using higher cut-off levels below which trade is
} 
Figure 1: Fraction of Surviving Spells over Calendar Time

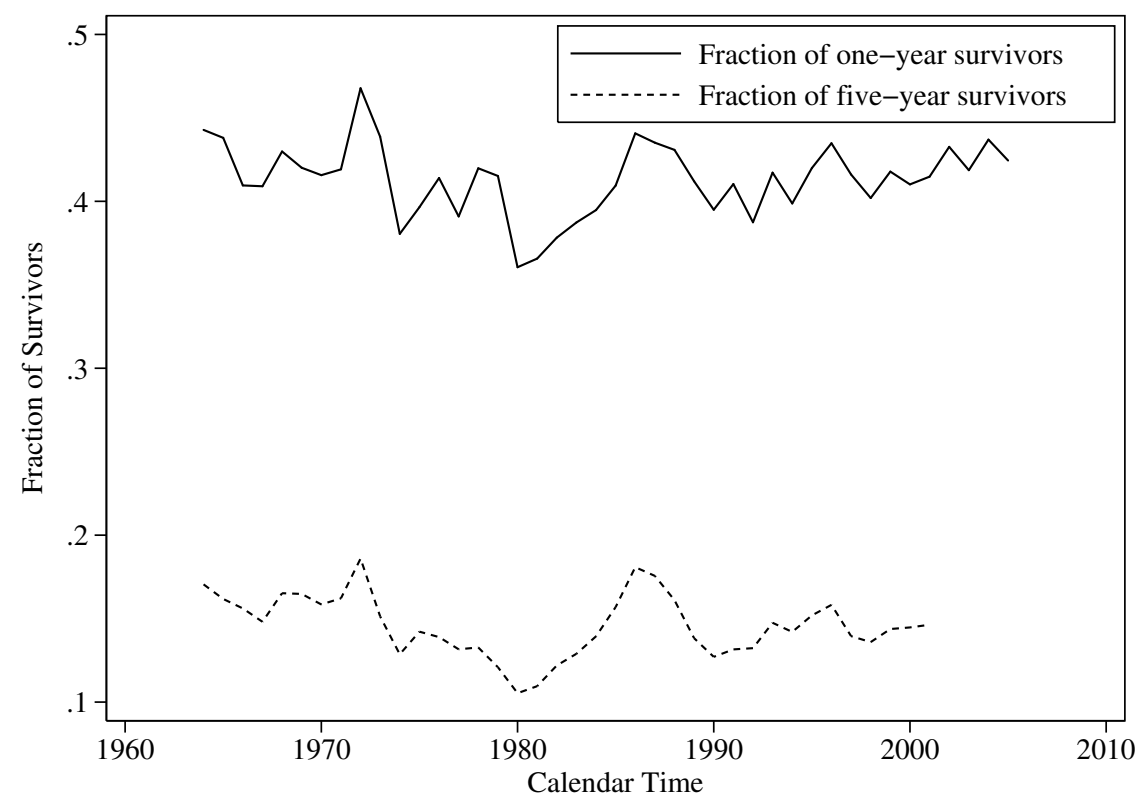

Source: Hess and Persson (2011b)

As noted above, one of the most intriguing results in Hess and Persson (2011b) was that short duration is a persistent characteristic of trade throughout the observed time period. This point is illustrated in Figure 1, which shows that the fractions of spells that survive the first and fifth year of service do not really change over calendar time but fluctuate around roughly 40 and 15 percent, respectively. There are certainly many short term fluctuations from one year to another, but the overall conclusion drawn in Hess and Persson (2011b) was nevertheless that short duration is a persistent characteristic of trade throughout the observed time period. In other words, despite all changes that have taken place in the world economy over this period, trade relationships died very early to the same extent in the 1960s as they do today. Why is this the case? We will use the results of a regression analysis to shed some light on this issue.

\section{Regression Analysis}

Our regression analysis follows Hess and Persson (2011b), so we refer the reader to that article for all details, including results on all robustness regressions. Since we will use not counted also has only minor effects. Lastly, aggregating the data all the way up to the 1-digit level where there are only ten remaining categories of products results in a median duration of imports of 2 years. 
the regression estimates in our exploration of the evolution of trade survival over calendar time, we will here replicate the main results.

To say a few words about the methodology, as shown by Hess and Persson (2011a), there are several reasons why - despite its popularity in this literature - it is inappropriate to apply the Cox model when analyzing determinants of trade durations. We therefore use more appropriate discrete-time duration models with proper controls for unobserved heterogeneity. We estimate the baseline specification using discrete-time probit, logit, and cloglog models. All left-censored observations, which, if included, could lead to bias in the estimated hazard rate, are excluded. In all models, we include random effects for every exporter-product combination. ${ }^{6}$ We estimate our main model for four different time periods: the full period from 1962 to 2006, and then three shorter time periods starting in 1970, 1980 and 1990. Since Hess and Persson (2011b) found that a probit model had the best fit for the data at hand, we only present results from that model. Results for the logit and cloglog models are available in Hess and Persson (2011b).

The results from the estimations can be found in Table 1. Table A.2 in the Appendix provides an overview of all variables and data sources. Note that, in addition to the explanatory variables whose parameters we will discuss shortly, the model also includes a large set of dummy variables aimed to control for unobserved heterogeneity. Our random effects control for all unobserved heterogeneity that is constant within exporter-product combinations. In addition, we include importer dummies to capture structural differences between importing countries and dummy variables capturing the number of previous spells for any given trade relationship (technically speaking, the latter are needed because our estimation methods assume that all spells are independent conditional on the covariates). We also model the baseline hazard in the most flexible possible fashion by means of dummy variables that enable the estimation of period-specific intercepts. This, in turn, allows for unrestricted period-specific changes in the estimated hazard rates. Lastly, and most importantly, we include calendar year dummies to control for all such latent factors that are common to all country pairs and products in a given year, but vary over time. We will return to the interpretation of these dummies in Section 4.

For a lengthy discussion of the included explanatory variables and their theoretical background, we refer the reader to Hess and Persson (2011b). Here, we will summarize the main results. All included covariates have highly significant coefficients. Distance increases the hazard that trade relationships will die, whereas having a common language or a joint colonial history decreases the hazard. Economically large importers experience a lower hazard of having trade flows die, while the opposite is found for economically large exporters. As discussed in Hess and Persson (2011b), the latter is, however, not a robust

\footnotetext{
${ }^{6}$ It may be noted that likelihood-ratio tests strongly reject the null hypothesis of no latent heterogeneity for all model specifications, implying that unobserved heterogeneity plays a significant role in all model specifications and should not be ignored.
} 
Table 1: Estimations Results

\begin{tabular}{|c|c|c|c|c|}
\hline & Full period & $1970-2006$ & $1980-2006$ & 1990-2006 \\
\hline Log distance & $\begin{array}{r}0.0396 \\
(0.000)\end{array}$ & $\begin{array}{r}0.0609 \\
(0.000)\end{array}$ & $\begin{array}{r}0.0607 \\
(0.000)\end{array}$ & $\begin{array}{r}0.0493 \\
(0.000)\end{array}$ \\
\hline Common language & $\begin{array}{r}-0.1890 \\
(0.000)\end{array}$ & $\begin{array}{r}-0.1701 \\
(0.000)\end{array}$ & $\begin{array}{r}-0.1813 \\
(0.000)\end{array}$ & $\begin{array}{r}-0.1924 \\
(0.000)\end{array}$ \\
\hline Colonial history & $\begin{array}{r}-0.1032 \\
(0.000)\end{array}$ & $\begin{array}{r}-0.1241 \\
(0.000)\end{array}$ & $\begin{array}{r}-0.1222 \\
(0.000)\end{array}$ & $\begin{array}{r}-0.0991 \\
(0.000)\end{array}$ \\
\hline $\begin{array}{l}\text { Log GDP } \\
\text { (importer) }\end{array}$ & $\begin{array}{r}-0.2858 \\
(0.000)\end{array}$ & $\begin{array}{r}-0.2833 \\
(0.000)\end{array}$ & $\begin{array}{r}-0.3360 \\
(0.000)\end{array}$ & $\begin{array}{r}-0.4202 \\
(0.000)\end{array}$ \\
\hline $\begin{array}{l}\text { Log GDP } \\
\text { (exporter) }\end{array}$ & $\begin{array}{c}0.0085 \\
(0.000)\end{array}$ & $\begin{array}{r}-0.0179 \\
(0.000)\end{array}$ & $\begin{array}{r}-0.0347 \\
(0.000)\end{array}$ & $\begin{array}{r}-0.0672 \\
(0.000)\end{array}$ \\
\hline Exporter LDC & $\begin{array}{r}-0.0572 \\
(0.000)\end{array}$ & $\begin{array}{r}-0.0900 \\
(0.000)\end{array}$ & $\begin{array}{r}-0.0909 \\
(0.000)\end{array}$ & $\begin{array}{r}-0.0875 \\
(0.000)\end{array}$ \\
\hline $\begin{array}{l}\text { Log number of } \\
\text { export products }\end{array}$ & $\begin{array}{r}-0.2294 \\
(0.000)\end{array}$ & $\begin{array}{r}-0.2845 \\
(0.000)\end{array}$ & $\begin{array}{r}-0.2906 \\
(0.000)\end{array}$ & $\begin{array}{r}-0.2269 \\
(0.000)\end{array}$ \\
\hline $\begin{array}{l}\text { Number of } \\
\text { export markets }\end{array}$ & $\begin{array}{r}-0.0885 \\
(0.000)\end{array}$ & $\begin{array}{r}-0.0772 \\
(0.000)\end{array}$ & $\begin{array}{r}-0.0679 \\
(0.000)\end{array}$ & $\begin{array}{r}-0.0511 \\
(0.000)\end{array}$ \\
\hline Lagged duration & $\begin{array}{r}-0.0188 \\
(0.000)\end{array}$ & $\begin{array}{r}-0.0251 \\
(0.000)\end{array}$ & $\begin{array}{r}-0.0328 \\
(0.000)\end{array}$ & $\begin{array}{r}-0.0521 \\
(0.000)\end{array}$ \\
\hline $\begin{array}{l}\text { Log initial } \\
\text { import value }\end{array}$ & $\begin{array}{r}-0.0760 \\
(0.000)\end{array}$ & $\begin{array}{r}-0.0755 \\
(0.000)\end{array}$ & $\begin{array}{r}-0.0763 \\
(0.000)\end{array}$ & $\begin{array}{r}-0.0765 \\
(0.000)\end{array}$ \\
\hline $\begin{array}{l}\text { Differentiated } \\
\text { product }\end{array}$ & $\begin{array}{r}-0.1095 \\
(0.000)\end{array}$ & $\begin{array}{r}-0.1311 \\
(0.000)\end{array}$ & $\begin{array}{r}-0.1516 \\
(0.000)\end{array}$ & $\begin{array}{r}-0.1579 \\
(0.000)\end{array}$ \\
\hline $\begin{array}{l}\text { Log total } \\
\text { import value }\end{array}$ & $\begin{array}{r}-0.0198 \\
(0.000)\end{array}$ & $\begin{array}{r}-0.0376 \\
(0.000)\end{array}$ & $\begin{array}{r}-0.0415 \\
(0.000)\end{array}$ & $\begin{array}{r}-0.0393 \\
(0.000)\end{array}$ \\
\hline EU member & $\begin{array}{r}-0.0427 \\
(0.000)\end{array}$ & $\begin{array}{r}-0.0436 \\
(0.000)\end{array}$ & $\begin{array}{r}-0.0741 \\
(0.000)\end{array}$ & $\begin{array}{r}-0.1387 \\
(0.000)\end{array}$ \\
\hline $\begin{array}{l}\Delta \text { log relative } \\
\text { real exchange rate }\end{array}$ & $\begin{array}{r}0.0675 \\
(0.000)\end{array}$ & $\begin{array}{r}0.0736 \\
(0.000)\end{array}$ & $\begin{array}{r}0.1143 \\
(0.000)\end{array}$ & $\begin{array}{r}0.1192 \\
(0.000)\end{array}$ \\
\hline Duration dummies & yes & yes & yes & yes \\
\hline Year dummies & yes & yes & yes & yes \\
\hline Importer dummies & yes & yes & yes & yes \\
\hline Spell no. dummies & yes & yes & yes & yes \\
\hline$\rho$ & $\begin{array}{r}0.0561 \\
(0.000)\end{array}$ & $\begin{array}{r}0.0856 \\
(0.000)\end{array}$ & $\begin{array}{r}0.1052 \\
(0.000)\end{array}$ & $\begin{array}{r}0.1147 \\
(0.000)\end{array}$ \\
\hline Observations & 2220871 & 1887638 & 1432718 & 895433 \\
\hline Spells & 692148 & 640848 & 531054 & 381658 \\
\hline Trade relations & 265396 & 256058 & 236630 & 202567 \\
\hline Log likelihood & -895709 & -813386 & -651646 & -444489 \\
\hline
\end{tabular}

Note: $P$-values in parentheses. In all columns, a probit model with exporter-product random effects has been estimated, but on samples that cover various time periods. $\rho$ denotes the fraction of the error variance that is due to variation in the unobserved individual factors. A trade relation is defined as an importerexporter-product combination. The number of observations is given by the total number of years with positive trade for all trade relationships. 
result. Least developed countries will, everything else being equal, tend to have more long-lived export spells. Countries with a diversified export structure - either in terms of exporting many products or exporting the product in question to many destination countries - will have lower hazards than countries which trade few products and/or have few trading partners. If two countries have previously traded a particular product for an extended period of time, this will lower the hazard of the current trade flow dying. If the trade flow has a large initial value, if a differentiated product is involved, or if the total EU market for the product is large, the hazard is decreased. Countries that have already joined the EU will also face a lower risk of bilateral import flows dying. Lastly, just as one would expect, an appreciation of the exporter's (relative) real exchange rate increases the risk that the trade flow will die. As shown in Hess and Persson (2011b), using alternative ways to define a spell, controlling for unobserved heterogeneity by means of fixed rather than random effects or aggregating the trade data, produces only marginal changes in the results. Interestingly, as can be seen in Table 1, using alternative time periods in our regressions does not lead to large changes in the results. The only exception is that the unexpected positive coefficient for the size of the exporter's GDP is turned into a negative coefficient as soon as we drop data from the 1960s. Apart from this, the similarity of the results regardless of time period is consistent with the finding that trade flows' survival does not change much over calendar time.

\section{Exploring the Evolution of Trade Duration over Calendar Time}

One of the most striking findings in Hess and Persson (2011b) was that short duration is a persistent characteristic of trade throughout the very long time period under study. Specifically, the first- and fifth-year survival rates were found to fluctuate around a fairly constant level from as early as the 1960s until the 2000s. Since this is a new finding which has not previously been analyzed in the literature, we will in this section attempt to shed some further light on the issue. Specifically, we will use the results from the regression analysis to investigate why the duration of trade does not change much over calendar time.

In the regression analysis, we found several independent variables having a statistically significant effect on the hazard of trade flows dying. Most of these variables have negative coefficients, implying that the more they increase, the lower the hazard will be. In turn, this implies that if these variables exhibit any long-term upward or downward trend over the time period under study, this should have a long-term effect on the duration of trade. To investigate this issue, we begin, in Figure 2, by plotting the yearly unweighted averages of all the time-varying explanatory variables. ${ }^{7}$

\footnotetext{
${ }^{7}$ Regarding the dummy for EU membership, we have - for ease of interpretation - simply plotted the actual number of EU members, rather than an average of the dummy variable. Note that we in this
} 
Figure 2: Explanatory Variables' Trends over Calendar Time

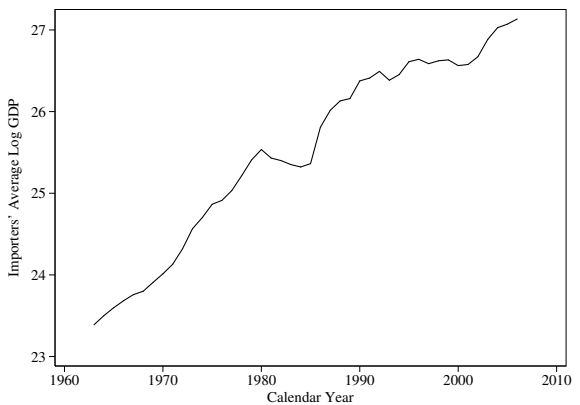

(a) Importers' average log GDP

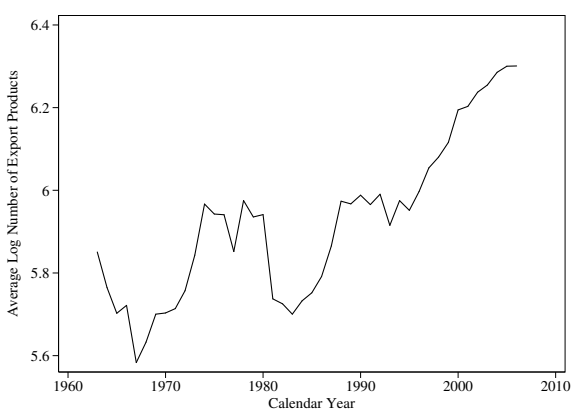

(c) Average log number of export products

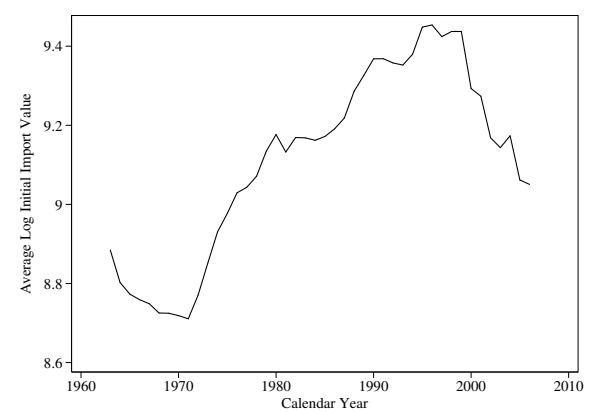

(e) Average log initial import value

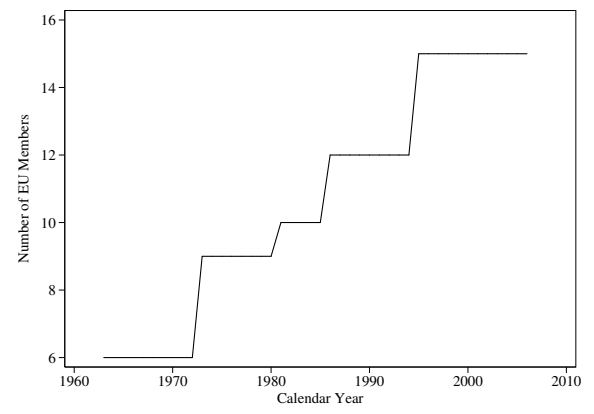

(g) Number of EU members

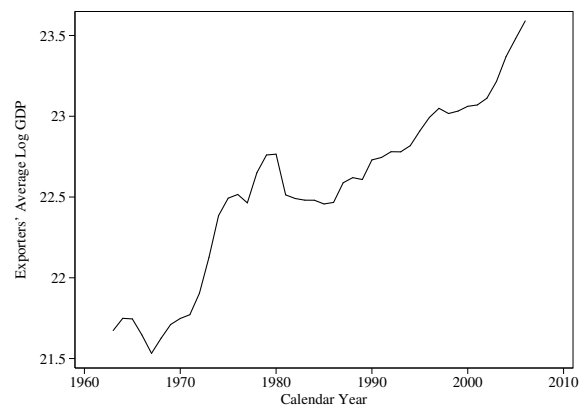

(b) Exporters' average log GDP

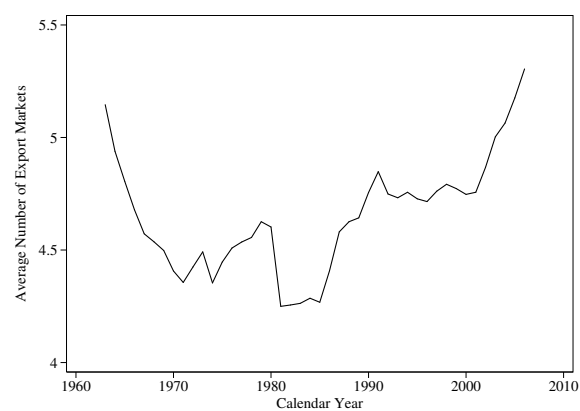

(d) Average number of export markets

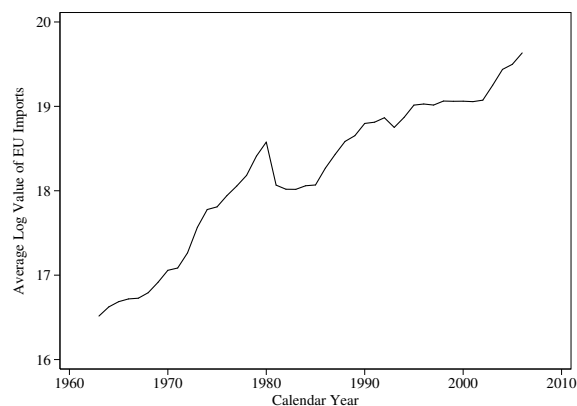

(f) Average log value of EU imports

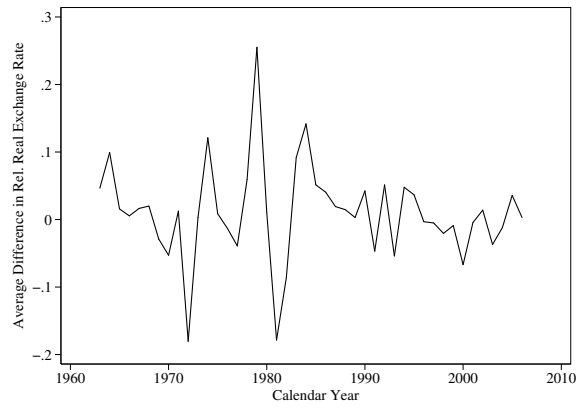

(h) Average difference in log rel. real exchange rate

9 
Figure 2 shows that five of the variables - GDP for the importers and exporters, the number of exported products, the value of EU imports, and EU membership - exhibit a clear long-term upward trend. For the remaining three, there is not as clear a long-term trend in either direction. Since the upward-trending variables all have negative coefficients, ${ }^{8}$ this suggests that there should be a long-term downward trend in the hazard. In other words, since several of the variables which, according to our model, have significantly negative effects on the hazard exhibit positive trends over time, this should result in the hazard of trade flows dying becoming smaller and smaller throughout the time period under study.

To identify these effects, in Figure 3 (the graph called "Hazard 1"), we have plotted the estimated first-year hazard over calendar time for period-specific means of covariates, holding the calendar-year dummies fixed at their 1963-value. This allows us to single out the effects of the observed explanatory variables on the hazard, while disregarding any (calendar-year specific) changes in the hazard due to other factors. The graph confirms what one would expect: the long-term trends in the model's explanatory variables, such as the trading countries' GDP or the level of export diversification, have contributed to lowering the hazard of trade flows dying. The effect is quite large indeed, with the estimated first-year hazard going from a level of $34 \%$ at the beginning of the period to a level of $3 \%$ at the end.

The calendar year dummies included in the estimated model capture all effects on the hazard which are common for all trade relationships in a given year, but differ over calendar time. As illustrated in Figure 4, the dummies' coefficients exhibit a positive upward trend. To see how this affects the estimated first-year hazards, in the second graph ("Hazard 2") of Figure 3, the estimated first-year hazard is plotted, holding all other covariates at their 1963-value so that changes over time on the first-year hazard solely stem from the calendar year effects. As expected, given the positive trend in the estimated coefficients for the calendar year dummies, the first-year hazard now exhibits an upward trend, so that the hazard of a trade relationship dying is much greater at the end of the period. The change is even more substantial than the one found when focusing on the observed explanatory variables: the hazard increases from $34 \%$ to $90 \%$ over the time period under study.

In the last graph of Figure 3 ("Hazard 3"), the estimated first-year hazard is plotted, using period-specific averages of all covariates. In other words, both the downward trend in hazard due to changes in the observed explanatory variables and the upward trend in

illustration separate Luxembourg and Belgium even though they are actually treated as one entity in the trade statistics. It should further be noted that while the only remaining time-varying variable, namely the lagged duration, potentially could have a long-term trend, we have not included that variable here, as it was demonstrated above that the duration of trade does not exhibit any long-term trend.

${ }^{8}$ The only exception being the Exporter's GDP, for which, however, as discussed in Hess and Persson (2011b), the unexpected positive sign in the baseline regression is turned into a negative sign in several of the robustness analyses. 
Figure 3: First-Year Hazards over Calendar Time

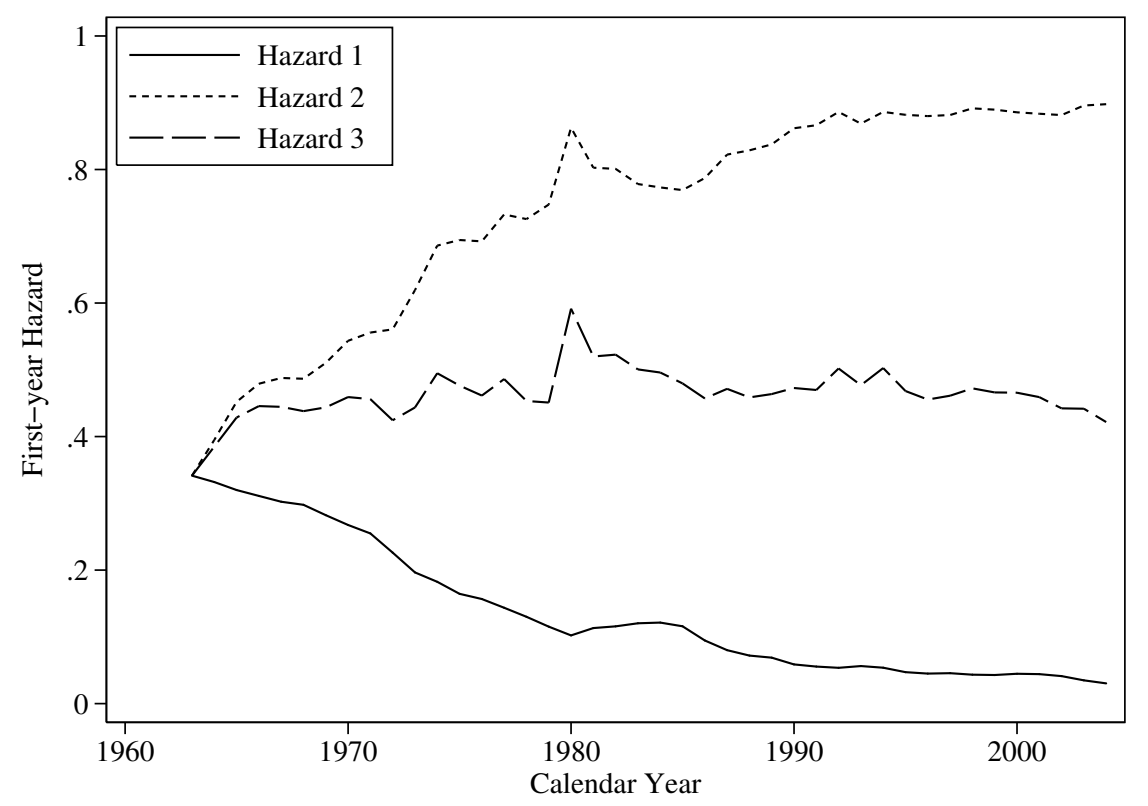

Note: "Hazard 1" is the estimated first-year hazard over calendar time when changes in the estimated calendar year dummies do not contribute to the hazard, so that changes in the hazard are solely driven by changes in the observed covariates. "Hazard 2 " is the corresponding graph when all observed covariates are held at their 1963-value, so that only changes in the estimated calendar year effects contribute to the hazard. "Hazard 3" is the same graph at period-specific means of all covariates.

hazard due to the calendar year effects are taken into account here. Evidently, this results in the same type of pattern that was found for the empirical fraction of first-year survivors in Figure 1 above: the estimated first-year hazard and the observed fraction of first-year survivors both fluctuate around a fairly constant level throughout the long time period.

To summarize, while short duration is a persistent characteristic of trade over the long time period that we study, this constancy is the result of two trends that work in opposite directions. On the one hand, positive trends in several of the observed explanatory variables - which in turn influence the hazard in a negative direction - imply that the hazard tends to decrease over calendar time. On the other hand, there is also a positive trend in the hazard due to calendar year-specific unobserved factors. In other words, when disregarding the effects of the observed explanatory variables, there is an upward trend in the hazard, implying that trade flows, ceteris paribus, are more likely to die quickly at the end of the time period under study. Thus, if the observed determinants of trade duration, such as GDP or level of export diversification, had not changed since the beginning of the 1960s, the probability of a given trade flow dying in the first year of service would be almost three times higher at the end of the observation period. 
Figure 4: Estimated Coefficients for Calendar Year Dummy Variables

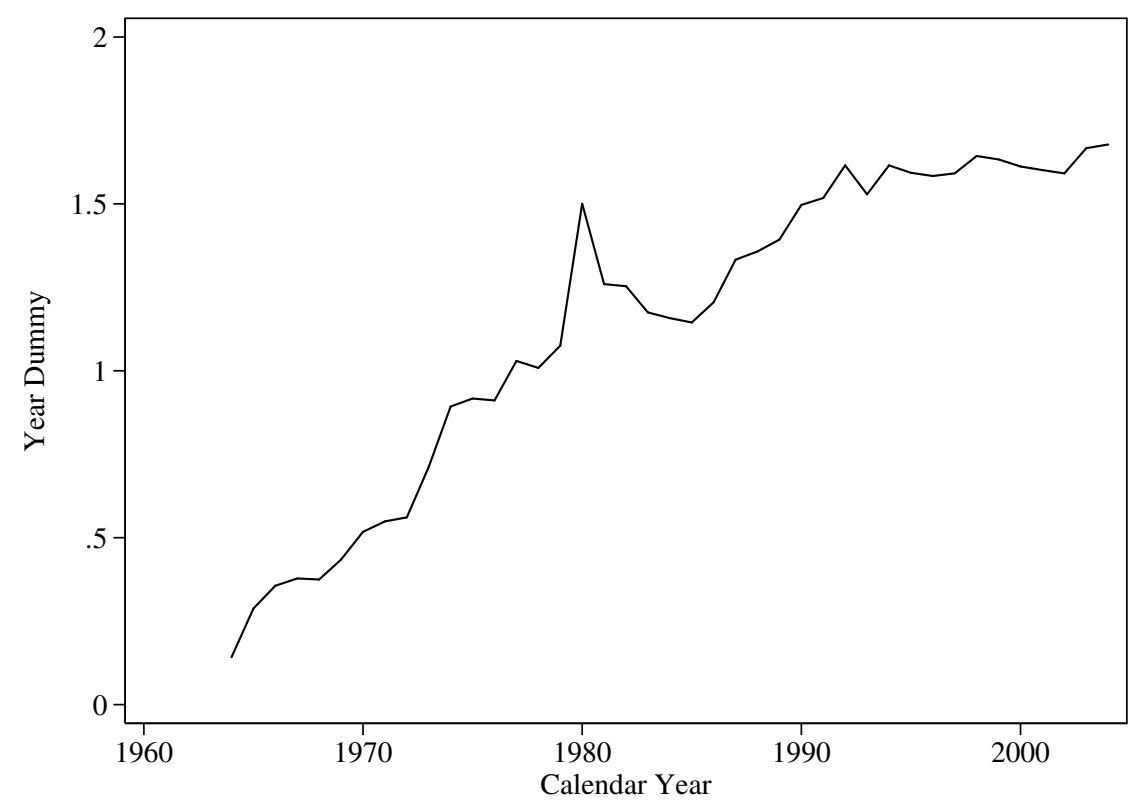

What is the explanation behind this upward trend in the hazard? Which unobserved factors influence the hazard to increase over calendar time? While we do not have any definitive answers, one area where we believe future research to be particularly beneficial is the varying importance of trade costs. A large literature within international economics has discussed that trade costs - for instance captured by distance - may not be equally important at different points in time. ${ }^{9}$ While it was anticipated that costs associated with distance would become less important due to e.g. falling transportation costs, empirical studies have tended to draw the opposite conclusion. As noted by e.g. Brun et al. (2005), gravity studies have tended to find increasing effects of distance over time, and the conclusion that distance is of increasing importance as an impediment to trade is corroborated by papers such as Berthelon and Freund (2008), Carrère and Schiff (2005) and Disdier and Head (2008). The latter paper, for instance, performs an ambitious meta-study of 1467 estimated distance effects from gravity studies, and finds that the elasticity of trade with respect to distance does not decline over the years, but rather increases. Of course, as noted by Carrère and Schiff (2005), there are two issues at stake here: even though trade costs - such as transportation costs - themselves fall, trade flows' sensitivity to a given level of trade costs could still increase. Reasons for an increased sensitivity could e.g. include a changing composition of trade, where distance could become more and more important as an impediment to trade due to the larger degree of time-sensitivity among

\footnotetext{
${ }^{9}$ For an overview of the literature on trade costs, see e.g. Anderson and van Wincoop (2004).
} 
traded goods in later years.

Relating this to our empirical study, we note that distance is restricted to have an effect which does not vary over calendar time in the baseline regression. If distance is becoming more and more important as a trade impediment over calendar time, this could perhaps explain the upward trend in the hazard as captured by the calendar year dummies. While we cannot completely rule out this type of explanation, we note that we do not find any support for it in our empirical results. As described above, part of our robustness analysis consisted of running the baseline regression on samples where observations from the 1960s, 1970s and 1980s were progressively removed. The consequence of this is effectively to allow all variables, including distance, to have an effect which varies over calendar time. While there are indeed some small differences between the estimated coefficients, when we compare survivor functions between the samples for different given values of distance, the differences are not particularly striking. ${ }^{10}$ This suggests that there must be other factors which have not been observed, but which exhibit strong enough trends over time to induce the hazard to increase. While further investigations of this issue are beyond the scope of this paper, it is indeed a promising area for future research.

\section{Summary and Conclusions}

The starting point for this paper was the empirical finding in Hess and Persson (2011b) that short duration is a persistent characteristic of trade for the period 1962-2006. In other words, despite the profound changes that have taken place in terms of integration of the world economy, trade flows died in their first year of service to the same extent in the 1960s as they do today. Since this is a noteworthy result and a dimension of trade duration which has not previously been explored, we use the data and regression results from Hess and Persson (2011b) to investigate the issue in more detail. We find that the lack of changes over calendar time is actually the result of two trends that work in opposite directions. On the one hand, positive trends in several of the observed explanatory variables - which in turn influence the hazard in a negative direction - imply that the hazard tends to decrease over calendar time. This then contributes to longer trade duration later in the studied time period. In fact, if we only take these effects into account, the estimated first-year hazard would have gone from $34 \%$ in the early 1960s to a level of only $3 \%$ in 2006 . On the other hand, there is also a positive trend in the hazard due to unobserved factors, which are captured by the calendar year dummies. In other words, when disregarding the observed explanatory variables, there is an upward trend in the hazard, implying that trade flows, ceteris paribus, are more likely to die quickly at the end of the time period under study. Holding all other determinants constant, the hazard of a trade flow dying in its first year increases from $34 \%$ at the beginning of the period to $90 \%$ at the end. While we at this

\footnotetext{
${ }^{10}$ Results are available upon request.
} 
point cannot identify the unobserved determinants that cause this increase in the hazard, we propose that trade flows' increasing sensitivity to trade costs could be one such factor. Analyzing this issue in more detail is certainly a promising area for future research.

We would like to offer a final comment on the interpretation of our findings. One way of looking at our results is that they illustrate that even though the literature has been able to identify factors which to some extent can explain the short trade durations we observe in the data, there are clearly many other factors which we simply do not understand yet. After all, had the identified explanatory factors been the only ones that mattered, most new trade relationships would have no particular problem surviving the first years of service today. This is definitively not what we observe in the data. In other words, there is yet much left to be explained by researchers about the determinants of trade survival. From a policy perspective, finding those factors is of great interest, because if most new trade relationships die very quickly after they have been created, this may act as a severe obstacle to much needed trade growth, particularly in poorer countries. 


\section{References}

Anderson, J. E. and VAn Wincoop, E. (2004), "Trade Costs", Journal of Economic Literature, vol. 42(3), pp. 691-751.

Berthelon, M. and Freund, C. (2008), "On the Conservation of Distance in International Trade", Journal of International Economics, vol. 75(2), pp. 310-320.

Besedeš, T. (2008), "A Search Cost Perspective on Formation and Duration of Trade", Review of International Economics, vol. 16(5), pp. 835-849.

Besedeš, T. (2011), "Export differentiation in transition economies", Economic Systems, vol. 35(1), pp. 25-44.

Besedeš, T. and Prusa, T. J. (2006a), "Ins, Outs and the Duration of Trade", Canadian Journal of Economics, vol. 39(1), pp. 266-295.

Besedeš, T. and Prusa, T. J. (2006b), "Product Differentiation and Duration of US Import Trade", Journal of International Economics, vol. 70(2), pp. 339-358.

Besedeš, T. and Prusa, T. J. (2010), "The Role of Extensive and Intensive Margins and Export Growth", Journal of Developement Economics, doi:10.1016/j.jdeveco.2010.08.013.

Brenton, P., Saborowski, C. and von UexkÜll, E. (2009), "What Explains the Low Survival Rate of Developing Country Export Flows", World Bank Policy Research Working Paper No. 4951.

Brun, J.-F., Carrère, C., Guillaumont, P. and de Melo, J. (2005), "Has Distance Died? Evidence from a Panel Gravity Model", World Bank Economic Review, vol. 19(1), pp. 99-120.

Cadot, O., Iacovone, L., Pierola, D. and Rauch, F. (2011), "Success and failure of African exporters", FREIT Working Paper No. 282.

Carrère, C. and Schiff, M. (2005), "On the Geography of Trade. Distance is Alive and Well", Revue Economique, vol. 56(6), pp. 1249-1274.

Disdier, A.-C. and Head, K. (2008), "The Puzzling Persistence of the Distance Effect on Bilateral Trade", Review of Economics and Statistics, vol. 90(1), pp. 37-48.

Feenstra, R. C. (1997), "U.S. Exports, 1972-1994: With State Exports and other U.S. Data", NBER Working Paper No. 5990.

Fugazza, M. and Molina, A. C. (2009), "The determinants of trade survival", HEID Working Paper No. 05/2009. 
Görg, H., Kneller, R. and Muraközy, B. (2007), "What Makes a Successful Export?", CEPR Discussion Paper No. 6614.

Hess, W. and Persson, M. (2011a), "The Duration of Trade Revisited. Continuous-Time vs. Discrete-Time Hazards", Empirical Economics, forthcoming.

Hess, W. and Persson, M. (2011b), "Exploring the Duration of EU Imports", Review of World Economics, online first, DOI: 10.1007/s10290-011-0106-x.

Ilmakunnas, P. and Nurmi, S. (2010), "Dynamics of Export Market Entry and Exit", Scandinavian Journal of Economics, vol. 112(1), pp. 101-126.

Nitsch, V. (2009), "Die Another Day: Duration in German Import Trade", Review of World Economics, vol. 145(1), pp. 133-154.

RAUCH, J. E. (1999), "Networks versus Markets in International Trade", Journal of International Economics, vol. 48(1), pp. 7-35.

Volpe-Martincus, C. and Carballo, J. (2008), "Survival of New Exporters in Developing Countries: Does It Matter How They Diversify?", Globalization, Competitivesness and Governability, vol. 2(3), pp. 30-49. 


\section{Appendix: Auxiliary Tables}

Table A.1: Overview of Exporting Countries

\begin{tabular}{l} 
Afghanistan, Algeria, Angola, Antigua and Barbuda, Argentina, Australia, Bahamas, \\
Bahrain, Bangladesh, Barbados, Belize, Benin, Bermuda, Bhutan, Bolivia, Brazil, \\
Brunei, Burkina Faso, Burundi, Cambodia, Cameroon, Canada, Cape Verde, \\
Central African Republic, Chad, Chile, China, Colombia, Comoros, Congo (Dem. Rep.), \\
Congo (Rep.), Costa Rica, Côte d'Ivoire, Djibouti, Dominica, Dominican Republic, \\
Ecuador, Egypt, El Salvador, Equatorial Guinea, Eritrea, Ethiopia, Fiji, \\
French Polynesia, Gabon, Gambia, Ghana, Greenland, Grenada, Guatemala, Guinea, \\
Guinea-Bissau, Guyana, Haiti, Honduras, Iceland, India, Indonesia, Iran, Iraq, \\
Israel, Jamaica, Japan, Jordan, Hong Kong, Kenya, Kiribati, Korea (Rep.), Kuwait, \\
Lao PDR, Lebanon, Libya, Liberia, Madagascar, Malawi, Malaysia, Maldives, Mali, \\
Mauritania, Mauritius, Mexico, Mongolia, Morocco, Mozambique, Nepal, New Caledonia, \\
New Zealand, Nicaragua, Niger, Nigeria, Norway, Oman, Pakistan, Panama, \\
Papua New Guinea, Paraguay, Peru, Philippines, Qatar, Rwanda, Samoa, San Marino, \\
São Tomé \& Principe, Saudi Arabia, Senegal, Seychelles, Sierra Leone, Singapore, \\
Somalia, Southern African Customs Union (Botswana, Lesotho, Namibia, South Africa, \\
Swaziland), Sri Lanka, St. Kitts \& Nevis, St. Lucia, St. Vincent \& the Grenadines, \\
Sudan, Suriname, Switzerland, Syria, Tanzania, Thailand, Togo, Tonga, Tunisia, \\
Trinidad and Tobago, Turkey, Uganda, United Arab Emirates, United States, Uruguay, \\
Vanuatu, Venezuela, Vietnam, Yemen, Zambia, Zimbabwe \\
\hline \hline
\end{tabular} 
Table A.2: Overview of Variables and Data Sources

\begin{tabular}{|c|c|}
\hline Variable & Definition \& Data Source \\
\hline Trade duration & $\begin{array}{l}\text { Length of trade spell in years. Constructed using 4-digit SITC } \\
\text { (Rev. 1) EU15 imports from the United Nations' Comtrade } \\
\text { (henceforth referred to as the UN Comtrade data). }\end{array}$ \\
\hline Log distance & $\begin{array}{l}\text { Log of distance in km between the trading countries' capitals. } \\
\text { Data from Centre d'études prospectives et d'informations (CEPII), } \\
\text { http://www.cepii.fr. }\end{array}$ \\
\hline Common language & $\begin{array}{l}\text { Takes the value one if the trading countries share the same } \\
\text { language. Data from CEPII, http://www.cepii.fr. }\end{array}$ \\
\hline Colonial history & $\begin{array}{l}\text { Takes the value one if the trading countries have a common } \\
\text { colonial history. Data from CEPII, http://www. cepii.fr. }\end{array}$ \\
\hline Log GDP & $\begin{array}{l}\text { Log of importer's or exporter's GDP. Data from the World Bank's } \\
\text { World Development Indicators (WDI) online. }\end{array}$ \\
\hline Exporter LDC & $\begin{array}{l}\text { Takes the value one if the exporter is classified as a least developed } \\
\text { country by the UN at the end of the time period studied. }\end{array}$ \\
\hline $\begin{array}{l}\text { Log number of } \\
\text { export products }\end{array}$ & $\begin{array}{l}\text { Log of the number of products shipped to any market by the } \\
\text { exporter for every year of the spell. } \\
\text { Constructed using the UN Comtrade data. }\end{array}$ \\
\hline $\begin{array}{l}\text { Number of } \\
\text { export markets }\end{array}$ & $\begin{array}{l}\text { Number of markets (not logged) to which the exporter ships the given } \\
\text { product for every year of the spell. } \\
\text { Constructed using the UN Comtrade data. }\end{array}$ \\
\hline Lagged duration & $\begin{array}{l}\text { Number of years that a previous spell of the same trade } \\
\text { relationship lasted. Constructed using the UN Comtrade data. }\end{array}$ \\
\hline $\begin{array}{l}\text { Log initial } \\
\text { import value }\end{array}$ & $\begin{array}{l}\text { Log of the value of imports at the beginning of the spell. } \\
\text { Constructed using the UN Comtrade data. }\end{array}$ \\
\hline $\begin{array}{l}\text { Differentiated } \\
\text { product }\end{array}$ & $\begin{array}{l}\text { Takes the value one if the product is classified as differentiated } \\
\text { according to Rauch (1999). } \\
\text { Data from "Jon Haveman's International Trade Data", } \\
\text { http://www.macalester.edu/research/economics/ } \\
\text { page/haveman/trade.resources/tradedata.html. } \\
\text { Concordance used to translate the Rauch classification from } \\
\text { SITC (Rev. 2) to SITC (Rev. 1) from Feenstra (1997), } \\
\text { http://cid.econ.ucdavis.edu/usixd/wp5990d.html. }\end{array}$ \\
\hline $\begin{array}{l}\text { Log total } \\
\text { import value }\end{array}$ & $\begin{array}{l}\text { Log of the total value of imports by all EU15 countries for the } \\
\text { given product and every year of the spell. } \\
\text { Constructed using the UN Comtrade data. }\end{array}$ \\
\hline EU member & $\begin{array}{l}\text { Binary variable indicating for every year of a spell whether the } \\
\text { respective importing country has - in the given calendar year - } \\
\text { already joined the EU or not. }\end{array}$ \\
\hline $\begin{array}{l}\Delta \text { log relative } \\
\text { real exchange rate }\end{array}$ & $\begin{array}{l}\text { Yearly difference in log relative real exchange rate, where the } \\
\text { relative real exchange rate is defined as nominal exchange rate } \\
\text { (importer currency/exporter currency) adjusted by the respective } \\
\text { consumer price indices and normalized by the average real } \\
\text { exchange rate of all exporting countries against the importing } \\
\text { country. Bilateral real exchange rates have been constructed } \\
\text { using US exchange rates and national consumer price indices } \\
\text { from the World Bank's WDI. }\end{array}$ \\
\hline
\end{tabular}

